\title{
Peningkatan Kompetensi Guru Matematika SMK Melalui Program Revitalisasi di PPPPTK BMTI
}

\author{
Joko Soebagyo ${ }^{1}$, Wahyu Purnama ${ }^{2}$ \\ 'Sekolah Tinggi Teknologi Wastukancana; Jl. Cikopak 53, Purwakarta; Indonesia; \\ jokosoebagyo@gmail.com \\ 2PPPPTK BMTI; Jl. Pesantren, Cimahi, Bandung, Indonesia; inisial.wp@gmail.com
}

\begin{abstract}
Abstrak
Penelitian ini bertujuan untuk menganalisis peningkatan kompetensi guru matematika SMK melalui program revitalisasi di PPPPTK BMTI. Jenis penelitian ini adalah eksperimen, dengan desain penelitian yang digunakan One-Group PretestPosttest Design. Populasi dalam penelitian ini adalah seluruh guru matematika SMK yang sudah mengikuti Uji Kompetensi Guru (UKG). Pengambilan sampel dilakukan dengan teknik stratified random sampling, dan hasilnya terpilih 24 guru matematika SMK se-Indonesia dengan nilai UKG tahun 2017 kurang dari 75 pada modul C dan F. Metode pengumpulan data yang digunakan yaitu posttest berupa tes online, kemudian data dianalisis menggunakan uji normalitas, uji homogenitas, uji t, uji gain dan uji efektifitas. Hasil penelitian menunjukkan bahwa rata-rata nilai UKG modul C tahun 2017 adalah 37,58 dan nilai rata-rata posttest 66,25 hal ini berarti kompetensi guru matematika SMK pada modul C mengalami peningkatan sebesar 28,67, dan besar rata-rata uji gain termasuk dalam kriteria sedang yaitu sebesar 0,46 atau $46 \%$. Sedangkan hasil penelitian pada modul $\mathrm{F}$ menunjukkan rata-rata nilai UKG tahun 2017 adalah 55,39 dan rata-rata nilai posttest 49,58 hal ini menunjukkan bahwa kompetensi guru matematika SMK pada modul $\mathrm{F}$ mengalami penurunan sebesar 5,81 , dan besar rata-rata uji gain sebesar $-0,13$ atau mengalami penurunan sebesar $13 \%$. Penelitian ini memberikan informasi bahwa program revitalisasi melalui PKB dapat meningkatkan kompetensi guru matematika pada modul $\mathrm{C}$ tetapi tidak pada modul F.
\end{abstract}

Kata Kunci. Kompetensi Guru Matematika SMK, PKB, Modul C, Modul F

\begin{abstract}
This study aimed to analyze the improvement of vocational competence of mathematics teachers through the revitalization program in PPPPTK BMTI. This type of research is experimental, research design used One-group pretest-posttest design. The population in this study are all vocational math teachers who have followed the Master Competency Test/Uji Kompetensi Guru (UKG). Sampling was done by
\end{abstract}

Euclid, p-ISSN 2355-1712, e-ISSN 2541-4453, Vol. 6, No. 2, pp. 130- 144 CLembaga Penelitian Universitas Swadaya Gunung Jati (UGJ), Cirebon. 
stratified random sampling technique, and the results were elected 24 math teacher SMK in Indonesia with UKG 2017 value less than 75 on the module C and F. The data collection method used is the posttest in the form of an online test, and then the data were analyzed using normality test, homogeneity test, $t$ test, test and test effectiveness gains. The results showed that the average value of UKG module $C$ in 2017 was 37.58 and the average value posttest 66, 25, this means that the competence of mathematics teachers of SMK module C increased by 28.67 , and the average size of the gain test is included in the criteria being that is equal to 0.46 or $46 \%$. While the research results on the F module shows the average value of UKG in 2017 was 55.39 and the average value of 49.58 posttest this case shows that the competence of vocational school math teacher in module $\mathrm{F}$ decreased by 5.81 , and the average size test a gain of -0.13 or decreased by $13 \%$. This study provides information that revitalization program through Profession Sustainable Development/Pengembangan Keprofesian Berkelanjutan (PKB) can improve math teacher competence in module C but not on the module F.

Keywords. Vocational Mathematics Teacher Competencies, PKB, Module C, Module $\mathrm{F}$

\section{Pendahuluan}

Di Indonesia, berbagai upaya telah dan sedang dilakukan untuk meningkatkan performa dan mutu/kualitas SMK (Arifin, 2012; Rahman, 2009; Slamet PH, 2013), diantaranya adalah dengan Revitalisasi Sekolah Menengah Kejuruan (SMK) (Wardani, 2016), sebagaimana diamanatkan dalam Instruksi Presiden (Inpres) nomor 9 Tahun 2016 (Sekretariat Kabinet Republik Indonesia, 2016).

Revitalisasi SMK dilaksanakan dengan dua pilar utama. Pilar pertama, mengantisipasi datangnya gelombang Revolusi Industri 4.0 dengan segala teknologi desruptif yang menyertainya. Pilar ini berorientasi pada penguatan jalinan SMK dengan dunia usaha dan industri (DUDI). Pilar kedua, berorientasi pada pengembangan keunggulan potensi wilayah sebagai keunggulan nasional untuk menciptakan daya saing bangsa. Keunggulan potensi wilayah ini sejalan dengan prioritas pembangunan nasional, yaitu Kemaritiman, Pariwisata, Pertanian, dan Industri Kreatif (Gintings, 2018).

Berdasarkan dua pilar utama tersebut di atas, dikembangkan enam isu strategis yang menjadi prioritas Revitalisasi SMK, yakni; 1) penyelarasan dan

Euclid, p-ISSN 2355-1712, e-ISSN 2541-4453, Vol. 6, No. 2, pp. 130- 144 (CLembaga Penelitian Universitas Swadaya Gunung Jati (UGJ), Cirebon. 
pemutakhiran kurikulum; 2) inovasi pembelajaran; 3) pemenuhan dan peningkatan profesionalitas guru dan tenaga kependidikan; 4) kemitraan sekolah dengan dunia usaha/dunia industri (DU/DI) dan perguruan tinggi; 5) standarisasi sarana dan prasarana utama; dan 6) penataan/pengelolaan kelembagaan.

PPPPTK BMTI mempunyai tugas dan fungsi mengembangkan dan memberdayakan pendidik dan tenaga kependidikan bidang mesin dan teknik industri (Nababan, 2009) mempunyai peran dan tanggung jawab besar yang berkaitan dengan isu strategis ketiga, yakni pemenuhan dan peningkatan profesionalitas guru dan tenaga kependidikan.

Sejalan dengan isu tersebut, tahun 2018 program PPPPTK BMTI diarahkan untuk mendukung Revitalisasi SMK dengan sasaran program berupa Pengembangan Keprofesian Berkelanjutan (PKB) melalui Pendidikan dan Pelatihan (Diklat) guru dan tenaga kependidikan serta Pendampingan di SMK Revitalisasi. Jumlah SMK Revitalisasi yang menjadi tangggung jawab dan binaan PPPPTK BMTI sebanyak 12 SMK di 7 Provinsi.

Revitalisasi SMK merupakan instruksi Presiden No. 9 tahun 2016 dalam rangka Peningkatan Kualitas dan Daya Saing Sumber Daya Manusia (SDM) Indonesia (Sulaeman \& Mona, 2017). Untuk mendukung program Revitalisasi di 12 SMK tersebut, perlu penguatan dan peningkatan profesionalitas guru bidang adaptif matematika. Peningkatan profesional guru matematika berarti meningkatkan kompetensi, baik dari segi mathematical content knowledge (Hine, 2015; Ma, 1999), mathematical knowledge for teaching (Beswick \& Goos, 2012; Stylianides \& Stylianides, 2010) dan pedagogical content knowledge (Akdoğan \& Să̆, 2018; Beswick \& Goos, 2012; Shulman, 2015).

Terkait dengan pedagogi, beberapa matematikawan dan profesional meyakini bahwa pedagogi terbaik untuk mengajarkan matematika kepada siswa teknik adalah dengan memperkenalkan dan menggunakan konsep-konsep dalam banyak aplikasi matematika yang diterapkan (Hassani, 2009). Sebagai contoh kalkulus sebagai salah satu fondasi teknik terkait dengan perilaku fisik produk rekayasa. Kalkulus terletak di pusat pendidikan matematika teknik yang digunakan dalam perumusan matematika dari masalah fisik. Formulasi

Euclid, p-ISSN 2355-1712, e-ISSN 2541-4453, Vol. 6, No. 2, pp. 130- 144 CLembaga Penelitian Universitas Swadaya Gunung Jati (UGJ), Cirebon. 
ini telah memberikan kontribusi yang signifikan terhadap sistematisasi teknik dan penguasaan tugas-tugas teknik (Pahl \& Damrath, 2001).

Pedagogi berasal dari bahasa Yunani paid yang berati "anak", sementara peserta diklat adalah orang-orang dewasa, maka dalam proses pembelajaran digunakan pendekatan pembelajaran andragogi, di mana pendekatannya berpandangan bahwa peserta memiliki self concept, orientasi akan kebutuhan, self-learning, pengalaman, orientasi kesiapan belajar, dan orientasi pada pembelajaran (Knowles, Holton, \& Swanson, 2005).

Dengan demikian, mata pelajaran matematika dan guru matematika di SMK merupakan pilar dan pondasi untuk mendukung penguasaan mata pelajaran produktif atau keahlian tertentu, serta menjadi bagian penting dalam kesuksesan program Revitasisasi SMK. Melalui program PKB dalam bentuk diklat, diharapkan kompetensi guru matematika di 12 SMK Revitalisasi wilayah binaan PPPPTK BMTI dapat meningkat, baik aspek pedagogi maupun profesionalnya.

Program peningkatan kompetensi guru Matematika SMK program Revitalisasi dilaksanakan PPPPTK BMTI dalam bentuk Pengembangan Keprofesian Berkelanjutan (PKB) melalui Pendidikan dan Pelatihan (Diklat) Guru. Diklat dilaksanakan pada periode 19 s.d. 24 Maret 2018, bertempat di Departemen TET dan Sains PPPPTK BMTI. Calon peserta yang dipanggil sebanyak 24 orang (lihat Tabel 1), dari 12 SMK Revitalisasi binaan PPPPTK BMTI, dengan rincian berikut.

Tabel 1. Daftar Peserta Diklat PKB 2018

\begin{tabular}{|c|c|c|c|c|}
\hline No & Pseudonum & Pseudonym & Pseudoschool & Propinsi \\
\hline 1 & $201502762 x x x$ & AS & SMK A & \multirow{2}{*}{$\begin{array}{l}\text { Sulawesi } \\
\text { Utara }\end{array}$} \\
\hline 2 & $201512458 x x x$ & MFD & SMK A & \\
\hline 3 & $201510426 x x x$ & $\mathrm{AP}$ & SMK B & \multirow{2}{*}{$\begin{array}{l}\text { Sulawesi } \\
\text { Tengah }\end{array}$} \\
\hline 4 & $201502617 x x x$ & SY & SMK B & \\
\hline 5 & $201502846 x x x$ & SL & SMK C & \multirow{2}{*}{$\begin{array}{l}\text { Kalimantan } \\
\text { Utara }\end{array}$} \\
\hline 6 & $201506627 x x x$ & RE & SMK C & \\
\hline 7 & 201510159xxx & ED & SMK D & \multirow{2}{*}{$\begin{array}{l}\text { Kalimantan } \\
\text { Timur }\end{array}$} \\
\hline 8 & $201503122 x x x$ & $\mathrm{HSH}$ & SMK D & \\
\hline 9 & 201512346xxx & HJS & SMK E & \multirow{3}{*}{ Jawa Barat } \\
\hline 10 & $201510663 x x x$ & HTN & SMK E & \\
\hline 11 & 201511047xxx & $\mathrm{HHH}$ & SMK F & \\
\hline
\end{tabular}

Euclid, p-ISSN 2355-1712, e-ISSN 2541-4453, Vol. 6, No. 2, pp. 130- 144 CLembaga Penelitian Universitas Swadaya Gunung Jati (UGJ), Cirebon. 


\begin{tabular}{|c|c|c|c|c|}
\hline 12 & $201503100 x x x$ & FN & SMK F & \\
\hline 13 & $201502435 x x x$ & $\mathrm{DN}$ & SMK G & \\
\hline 14 & $201508620 x x x$ & $\mathrm{RP}$ & SMK G & \\
\hline 15 & 201511899xxx & NDY & SMK H & \\
\hline 16 & 201511666xxx & UK & SMK H & \\
\hline 17 & 201510191xxx & $\mathrm{DA}$ & SMK I & \multirow{2}{*}{$\begin{array}{l}\text { Kalimantan } \\
\text { Barat }\end{array}$} \\
\hline 18 & $201501479 x x x$ & CIA & SMK I & \\
\hline 19 & $201502643 x x x$ & EK & SMK J & \multirow{6}{*}{$\begin{array}{l}\text { DKI } \\
\text { Jakarta }\end{array}$} \\
\hline 20 & $201501818 x x x$ & FR & SMK J & \\
\hline 21 & $201510467 x x x$ & FT & SMK K & \\
\hline 22 & $201512515 x x x$ & NS & SMK K & \\
\hline 23 & $201502617 x x x$ & SM & SMK L & \\
\hline 24 & $201500102 x x x$ & MCM & SMK L & \\
\hline
\end{tabular}

Sumber: PPPPTK BMTI

Modul (kelompok kompetensi) yang didiklatkan adalah modul C dan F. Modul C memuat kompetensi pedagogi tentang Pengalaman Belajar dan Materi Pembelajaran, sedangkan kompetensi profesional tentang Geometri. Adapun modul F memuat kompetensi pedagogi tentang Pengembangan Ekstrakurikuler untuk Aktualisasi Diri Peserta Didik, sedangkan kompetensi profesional tentang Kalkulus dan Geometri Analitik. Struktur program (materi diklat) beserta alokasi waktu yang diberikan dijabarkan dalam tabel berikut:

Tabel 2. Struktur Diklat PKB 2018

\begin{tabular}{clc}
\hline No & \multicolumn{1}{c}{ Materi Diklat } & $\begin{array}{c}\text { Alokasi } \\
\text { Waktu } \\
\text { (JP) }\end{array}$ \\
\hline $\mathbf{A}$ & Program Umum & $\mathbf{6}$ \\
\hline 1 & $\begin{array}{l}\text { Kebijakan Program Pengembangan Keprofesian } \\
\text { Berkelanjutan (PKB) }\end{array}$ & 2 \\
\hline 2 & $\begin{array}{l}\text { Penguatan Pendidikan Karakter (PPK) dan Gerakan Literasi } \\
\text { Sekolah (GLS) }\end{array}$ & 2 \\
\hline 3 & Pengembangan Soal USBN & 2 \\
\hline $\mathbf{B}$ & Program Pokok & $\mathbf{5 4}$ \\
\hline $\mathbf{1}$ & $\begin{array}{l}\text { Pendalaman Materi Pedagogi C: Pengalaman Belajar dan } \\
\text { Materi Pembelajaran }\end{array}$ & 8 \\
\hline 3 & Pendalaman Materi Profesional C: Geometri & 18 \\
\hline 4 & Pendalaman Materi Pedagogi F: Pengembangan & \\
\hline & Ekstrakurikuler untuk Aktualisasi Diri Peserta Didik & \\
\hline
\end{tabular}

Euclid, p-ISSN 2355-1712, e-ISSN 2541-4453, Vol. 6, No. 2, pp. 130- 144 (CLembaga Penelitian Universitas Swadaya Gunung Jati (UGJ), Cirebon. 


\begin{tabular}{lll}
\hline C & Program Penunjang & 2 \\
\hline 1 & Tes Akhir & 2 \\
\hline & Total & 60
\end{tabular}

Sumber: PPPPTK BMTI

Materi Program Umum diberikan dan disampaikan oleh pejabat struktural setelah acara pembukaan di Gedung Serbaguna. Materi Pokok berupa pendalaman 2 (dua) modul diberikan dan disampaikan oleh widyaiswara PPPPTK BMTI dibantu oleh Instruktur Nasional (IN) dari kalangan guru SMK yang telah memenuhi kriteria dan persyaratan sesuai Pedoman/Juknis PKB, bertempat di aula Departemen TET dan Sains.

Kegiatan belajar mengajar lebih mengedepankan pada pendalaman/eksplorasi materi dan pengerjaan masalah kontekstual serta soal-soal yang ada pada modul, termasuk bedah kisi-kisi soal Uji Kompetensi Guru (UKG). Metode yang digunakan berupa penugasan dan diskusi kelompok dengan pendekatan andragogy berbantuan Geogebra. Di akhir eksplorasi modul, dialokasikan presentasi hasil kerja untuk mendapatkan solusi terbaik dan masukan dari peserta/kelompok yang lain.

Di akhir kegiatan, diberikan materi postes secara daring (online) yang bertempat di Lab Data Info. Meskipun sebagai materi penunjang, skor yang didapat pada postes online ini merupakan nilai/raport UKG dari guru yang bersangkutan. Nilai pretes sebagai nilai awal adalah nilai yang diperoleh guru yang bersangkutan pada UKG sebelumnya.

\section{Metode Penelitian}

Jenis penelitian yang digunakan dalam penelitian ini adalah eksperimen yang bertujuan untuk melihat pengaruh perlakuan yang diberikan dalam kondisi tertentu. Untuk mencapai tujuan tersebut, digunakan desain penelitian OneGroup Pretest-Posttest Design, dimana perlakuan dilakukan selama $60 \mathrm{JP}$ (lihat Tabel 2) dengan Program Pokok sebesar 54 JP.

\begin{tabular}{ccc} 
The One-Group Pretest-Posttest Design & \\
\hline$O$ & $X$ & $O$ \\
Pretest & Treatment & Posttest \\
\hline
\end{tabular}

Gambar 1. Desain Penelitian

Euclid, p-ISSN 2355-1712, e-ISSN 2541-4453, Vol. 6, No. 2, pp. 130- 144 (CLembaga Penelitian Universitas Swadaya Gunung Jati (UGJ), Cirebon. 
Populasi dalam penelitian ini adalah seluruh guru matematika SMK seIndonesia, dan pengambilan sampel dilakukan dengan teknik stratified sampling karena sampel diambil berdasarkan nilai UKG pada tahun 2017 dengan kriteria nilai di bawah 75. Berdasarkan teknik stratified tersebut diperoleh sampel sebanyak 24 guru matematika SMK dengan kriteria di bawah 75 pada modul C dan F.

Variabel bebas dalam penelitian ini adalah program PKB yang lebih mengedepankan pada pendalaman/eksplorasi materi dan pengerjaan masalah kontekstual serta soal-soal yang ada pada modul, termasuk bedah kisi-kisi soal Uji Kompetensi Guru (UKG). Metode yang digunakan berupa penugasan dan diskusi kelompok dengan pendekatan andragogy. Di akhir eksplorasi modul, dialokasikan presentasi hasil kerja untuk mendapatkan solusi terbaik dan masukan dari peserta/kelompok yang lain. Sedangkan variabel terikat adalah hasil belajar guru matematika SMK dengan indikator: kompetensi pedagogik dan profesional (nilai UKG dan nilai posttest), sikap, tugas, dan lembar pengamatan.

Metode pengumpulan data yang digunakan pada penelitian ini adalah tes formatif berbentuk pilhan ganda secara online. Instrumen tes yang digunakan dalam penelitian ini terdiri dari 10 kompetensi pedagogik dan 40 kompetensi profesional. Instrumen tes juga diuji validitas, reliabilitas, taraf kesukaran dan daya pembedanya.

\section{Hasil dan Pembahasan}

\subsection{Modul C}

Hasil uji analisis instrumen menyatakan bahwa uji validitas soal dilakukan melalui pengujian pakar oleh widyaiswara, dosen dan guru yang meliputi tiga aspek penilaian, yaitu aspek kontekstual, High Order Thinking (HOT) dan substansial. Disamping itu, instrumen tes formatif merupakan instrumen yang sudah diujikan kepada guru-guru matematika SMK dan mengalami revisi setiap tahunnya, baik dari segi kontekstual, substansial maupun HOT, sehingga reliabilitas, taraf kesukaran dan daya pembeda dari soal dapat dipertanggungjawabkan. 
Tabel 3. Data Nilai Pretest dan Posttest Modul C

\begin{tabular}{lrr}
\hline Komponen & Pretest & Posttest \\
\hline Julmlah Peserta & 24 & 24 \\
\hline Jumlah Nilai & 902 & 1590.00 \\
\hline Nilai Tertinggi & 57 & 86.67 \\
\hline Nilai Terendah & 14 & 36.67 \\
\hline Rata-rata & 37.58 & 66.25 \\
\hline Standar Deviasi & 17.03 & 11.85 \\
\hline
\end{tabular}

Berdasarkan hasil penelitian pada Tabel 3, menunjukkan bahwa program PKB mampu meningkatkan kompetensi guru matematika SMK pada modul C. Hal tersebut dapat dilihat dari perbandingan antara rata-rata pretest dan posttest pada sampel penelitian.

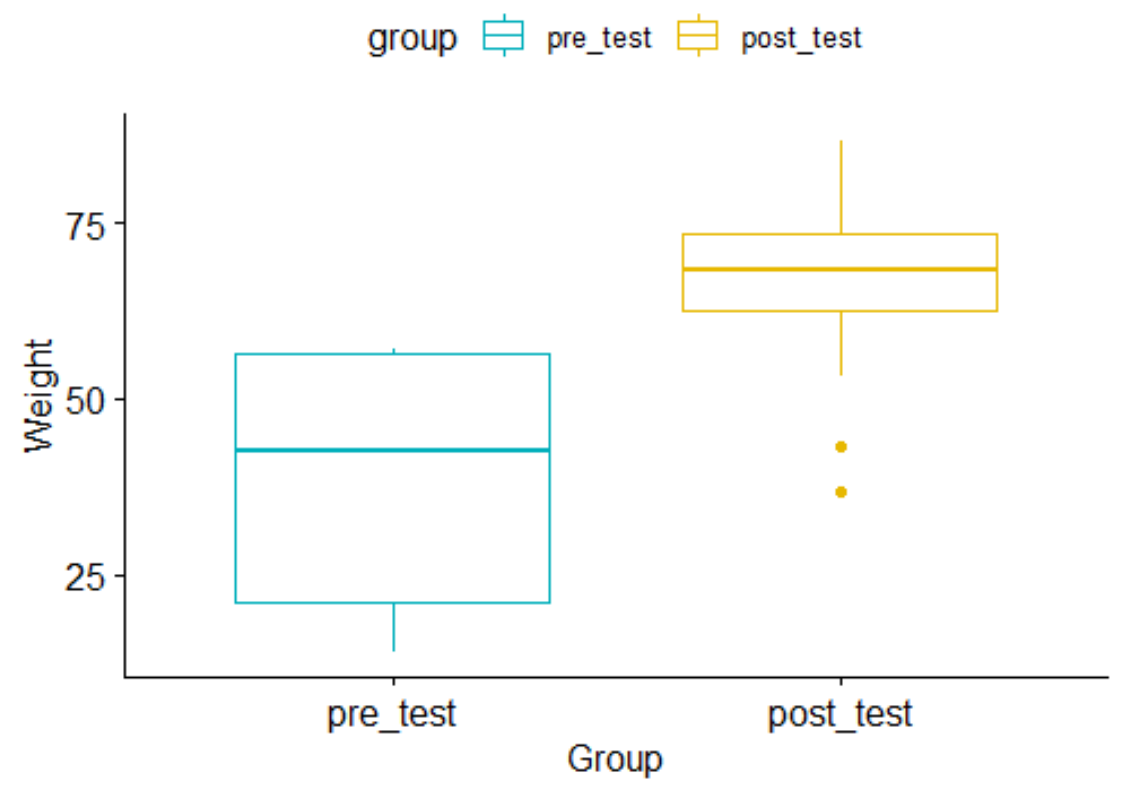

Gambar 2. Box Plot Nilai Kompetensi Modul C

Gambar 2 menunjukkan peningkatan kompetensi pada modul $\mathrm{C}$ tetapi akan lebih jelas lagi pada Gambar 3 pasangan nilai dalam modul C. 


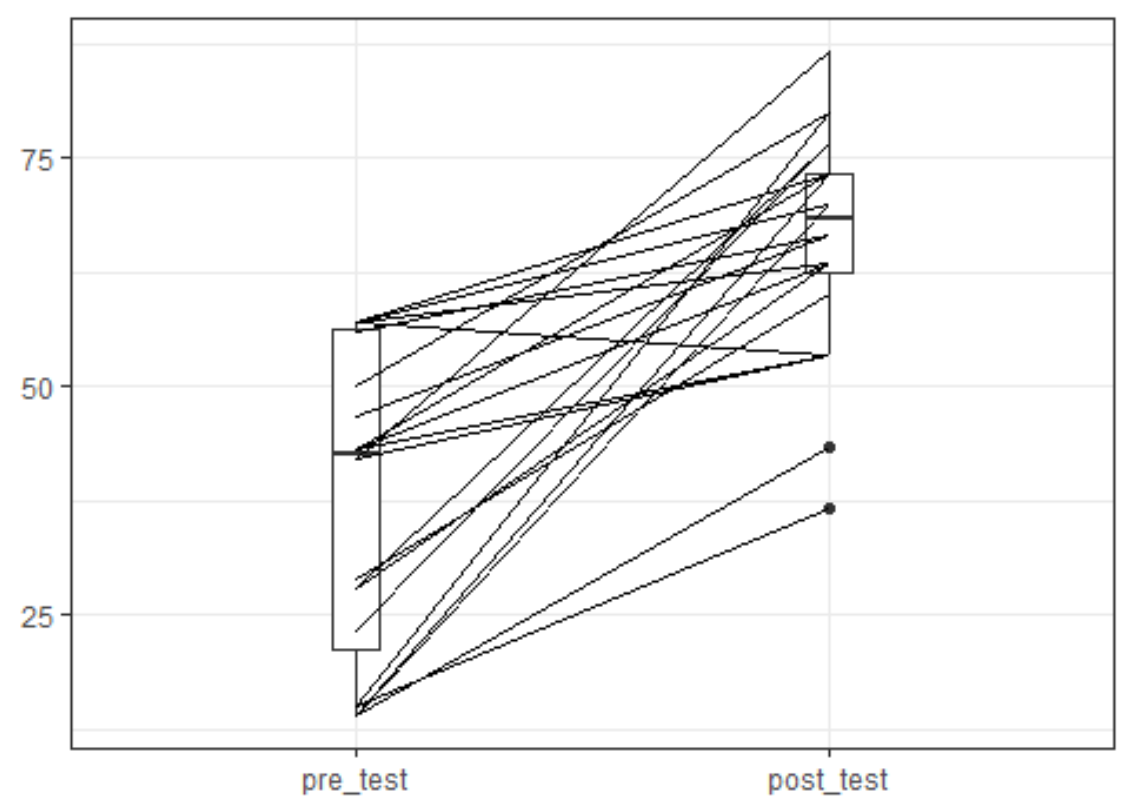

Gambar 3. Plot Paired Data Modul C

Untuk melihat lebih lanjut perbedaan rata-rata pada modul C, digunakan uji $t$ berpasangan tetapi sebelumnya dilakukan uji normalitas menggunakan uji shapiro-wilk. Hasil analisis diperoleh :

Shapiro-wi lk normality test

data: d

$\mathrm{w}=0.93928, p-$ value $=0.1572$

Karena nilai $p$-value $>0,05$ maka distribusi perbedaan antara nilai pretest dan posttest pada modul $\mathrm{C}$ tidak terdapat perbedaan secara signifikan dari distribusi normal. Dengan kata lain, data berdistribusi normal.

Paired t-test

data: weight by group

$\mathrm{t}=7.17, \mathrm{df}=23, \mathrm{p}$-value $=2.663 \mathrm{e}-07$

a7ternative hypothesis: true difference in means is not equal to 0 95 percent confidence interval: 20.3952636 .93640

sample estimates:

mean of the differences

28.66583

Hasil perhitungan $t$ hitung diperoleh 7,17 dan $p$ - value $<0,05$, maka dapat disimpulkan bahwa program PKB mempengaruhi nilai kompetensi guru SMK pada modul C. 


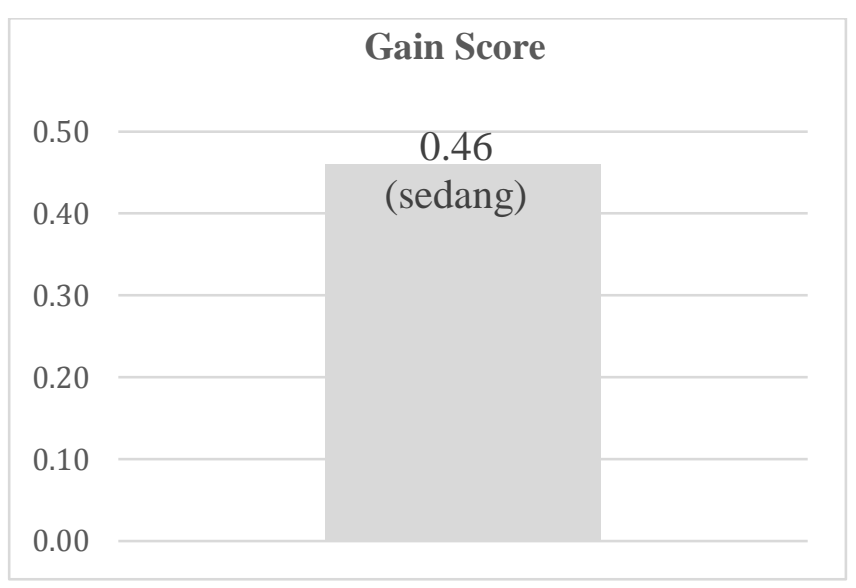

Gambar 4. Grafik Nilai Gain Modul C

Sedangkan berdasarkan uji gain dipeoleh nilai 0,46, seperti terlihat pada Gambar 4, yang menunjukkan bahwa peningkatan rata-rata kompetensi guru matematika SMK pada modul C termasuk dalam kriteria sedang.

Hasil dan temuan ini konsisten dengan penelitian Merrill, Devine, Brown, \& Brown, (2016) yang menyatakan bahwa penggunaan tools dalam pembelajaran Geometri menambah keyakinan guru matematika dalam pembelajaran matematika dan menambah pemahaman yang lebih baik pada siswa. Namun terdapat perbedaan pada penelitian ini, yaitu tools yang digunakan SolidWorks, dan pendekatan penelitiannya menggunakan action research.

\subsection{Modul F}

Tabel 4. Data Nilai Pretest dan Posttest Modul F

\begin{tabular}{lrr}
\hline Komponen & Pretest & Posttest \\
\hline Julmlah Peserta & 24 & 24 \\
\hline Jumlah Nilai & 1329.33 & 1190.00 \\
\hline Nilai Tertinggi & 83 & 73.33 \\
\hline Nilai Terendah & 20 & 20 \\
\hline Rata-rata & 55.39 & 49.58 \\
\hline Standar Deviasi & 15.01 & 14.59 \\
\hline
\end{tabular}




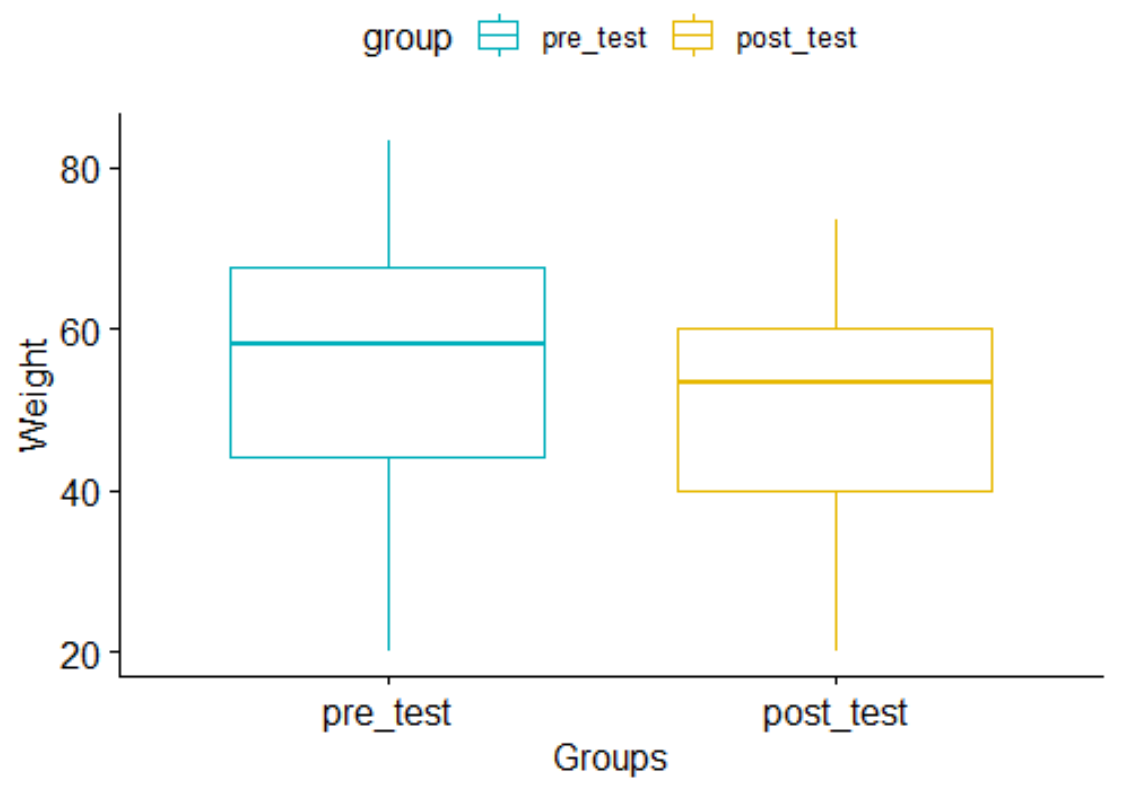

Gambar 5. Box Plot Nilai Kompetensi Modul F

Berdasarkan hasil penelitian pada Tabel 4, menunjukkan bahwa rata-rata pretest lebih besar daripada posttest pada modul F. Tetapi untuk melihat apakah penyebab perbedaan tersebut, akan digunakan pula uji $t$ sampel berpasangan. Kemudian pada Gambar 5 menunjukkan bahwa nilai rata-rata pretest pada modul $\mathrm{F}$ lebih besar daripada rata-rata posttest.

Sementara Gambar 6 menunjukkan secara jelas peningkatan dan penurunan yang dialami oleh guru SMK pada modul F. Terlihat terdapat peserta dengan nilai pretest yang rendah yang kemudian setelah melalui program PKB mengalami peningkatan pada nilai posttestnya. Di sisi lain, peserta dengan nilai pretest tertinggi justru mengalami penurunan pada nilai posttestnya setelah melalui program PKB. Akan tetapi terdapat beberapa guru mengalami peningkatan walaupun lebih sedikit jumlahnya daripada yang mengalami penurunan.

Hasil dan temuan pada modul F (Kalkulus dan Geometri Analitik) pada temuan ini, sejalan dengan temuan pada penelitian Turgut, Yenilmez, \& Anapa, (2014) yang menyatakan bahwa calon guru matematika memiliki skill rotasi yang buruk, dan penelitian ini juga mengungkap bahwa kemampuan spasial calon guru haruslah menjadi fokus utama. Namun terdapat perbedaan pada penelitian yang dilakukan oleh Turgut, yaitu metode 
penelitian yang digunakan menggunakan metode kualitatif tipe case study, lebih spesifik pada materi simetri dan rotasi, dan sampelnya calon guru.

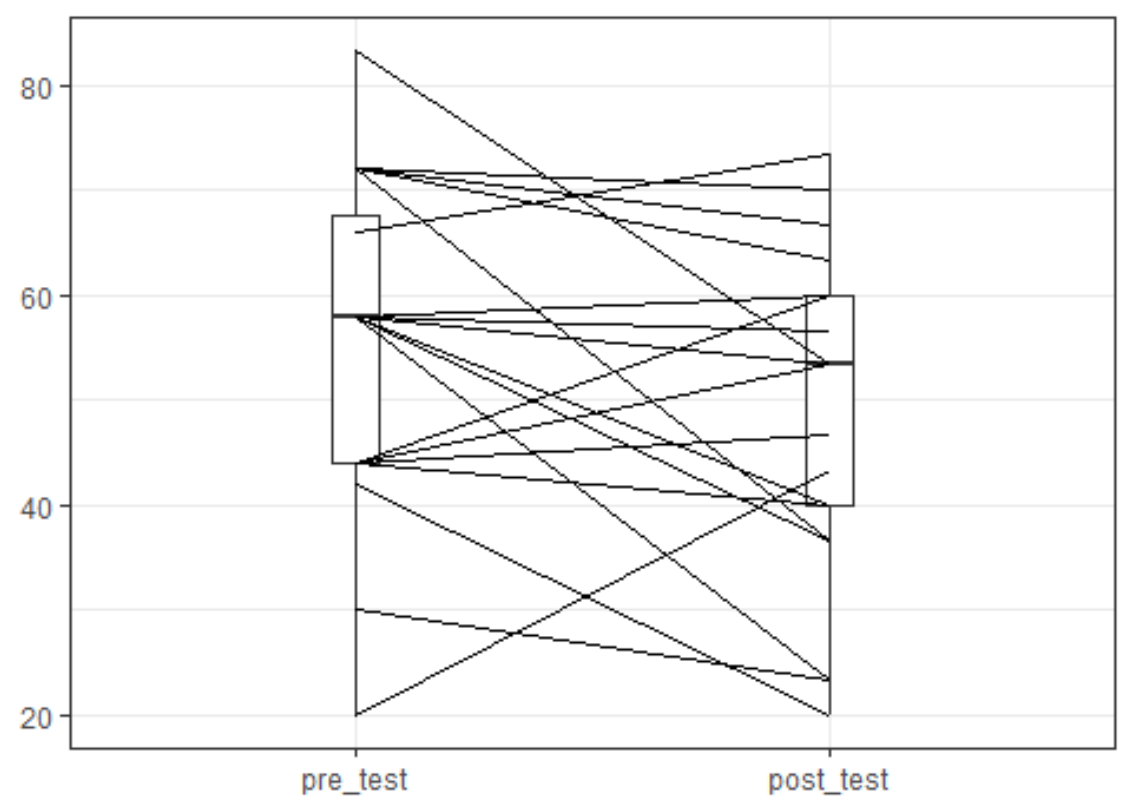

Gambar 6. Plot Paired Data Modul F

Hasil perhitungan uji normalitas pada modul F diperoleh:

Shapiro-wilk normality test

data: d

$\mathrm{w}=0.94755, \quad p-$ value $=0.2396$

Karena nilai $p$ - value $>0,05$, maka distribusi perbedaan antara nilai pretest dan posttest pada modul $\mathrm{F}$ tidak terdapat perbedaan secara signifikan dari distribusi normal. Dengan kata lain, data berdistribusi normal.

Paired t-test

data: weight by group

$\mathrm{t}=-1.9211, \mathrm{df}=23, \mathrm{p}-\mathrm{va}$ lue $=0.0672$

alternative hypothesis: true difference in means is not equal to 0

95 percent confidence interval:

$-12.0566960 .445863$

sample estimates:

mean of the differences

$-5.805417$

Hasil perhitungan $t$ hitung diperoleh $-1,92$ dan $p$-value $>0,05$, maka dapat disimpulkan bahwa program PKB tidak mempengaruhi nilai kompetensi 
guru SMK pada modul F. Sedangkan berdasarkan uji gain dipeoleh nilai 0,13 , yang menunjukkan bahwa terjadi penurunan rata-rata kompetensi guru matematika SMK pada modul F.

\section{Simpulan}

Berdasarkan hasil penelitian dan pembahasan, dapat disimpulkan bahwa program PKB dengan pendekatan andragogi dapat meningkatkan kompetensi guru matematika SMK pada modul $\mathrm{C}$, tetapi pada modul $\mathrm{F}$, program PKB dengan pendekatan andragogi belum memberikan peningkatan terhadap kompetensi guru matematika SMK.

Dengan demikian, untuk program PKB selanjutnya, khusus pada modul $\mathrm{F}$ perlu dilakukan perbaikan dan evaluasi ulang. Atau dilakukan kajian secara kualitatif untuk mengetahui penyebab mengapa terjadi penurunan dan kenaikan pada beberapa peserta.

\section{Daftar Pustaka}

Akdoğan, E. E., \& Sağ, G. Y. (2018). An Investigation on How Prospective Mathematics Teachers Design a Lesson Plan, 7(1987), 81-96. https://doi.org/10.7822/omuefd.313310

Arifin, Z. (2012). Implementasi manajemen stratejik berbasis kemitraan dalam meningkatkan mutu smk. Jurnal Administrasi Pendidikan, XIV(1), 60-70.

Beswick, K., \& Goos, M. (2012). Measuring Pre-Service Primary Teachers' Knowledge for Teaching Mathematics. Mathematics Teacher Education and Development, 14(2), 70-90. Retrieved from http://search.ebscohost.com/login.aspx?direct=true\&db=eric\&AN=EJ101 8656\&lang=es\&scope $=$ site

Fraenkel, J. R., Wallen, N. E., \& Hyun, H. H. (2012). How To Design And Evaluate Research In Education. (E. Edition, Ed.). New York: McGraw-Hill Companies Inc. https://doi.org/10.1017/CBO9781107415324.004

Gintings, E. (2018). Revitalisasi SMK: Solusi Kebekerjaan Lulusan SMK. Retrieved from

http://tedcbandung.com/web2018/html/index.php?id=artikel\&kode=1

Hassani, S. (2009). Mathematical Methods for Students of Physics and Related Fields 
(Second Edi). New York: Springer Science+Business Media, LLC.

Hine, G. S. C. (2015). Strengthening pre-service teachers ' mathematical content knowledge. Teaching and Learning Forum, 12(4), 1-11.

Knowles, M. S., Holton, E., \& Swanson, R. (2005). The Adult Learning: The Definitive Classic In Adult Education and Human Resource Development. Taylor and Francis.

Ma, L. (1999). Knowing and Teaching Elementary Mathematics: Teachers' understanding of funamental mathematics in China and the United States. https://doi.org/10.2307/749776

Merrill, C., Devine, K. L., Brown, J. W., \& Brown, R. A. (2016). Improving Geometric and Trigonometric Knowledge and Skill for High School Mathematics Teachers:A Professional Development Partnership. The Journal of Technology Studies, 36(2), 20-30. https://doi.org/10.21061/jots.v36i2.a.3

Nababan, W. (2009). Pengaruh Kepemimpinan dan Sikap Profesional Widyaiswara Terhadap Akademik Peserta Diklat di P4TK BMTI. Universitas Pendidikan Indonesia.

Pahl, P. J., \& Damrath, R. (2001). Mathematical Foundations of Computational Engineering: A Handbook. Berlin: Springer-Verlag Wien $\mathrm{GmbH}$. https://doi.org/10.1007/978-3-642-56893-0

Rahman, A. (2009). Pembinaan Profesional Guru SMK (Kajian Kualitatif Pada SMK di Bandung). Jurnal Tabularasa, 6(1), 26-14.

Sekretariat Kabinet Republik Indonesia. (2016). Salinan Inpres Nomer 9 Tahun 2016.pdf.

Shulman, L. (2015). Knowledge and Teaching: Foundations of the New Reform. Harvard Educational Review, 57(1), 1-23. https://doi.org/10.17763/haer.57.1.j463w79r56455411

Slamet PH. (2013). Pengembangan SMK Model untuk Masa Depan. Jurnal Cakrawala Pendidikan, 32(1), 14-26. https://doi.org/10.1017/CBO9781107415324.004

Stylianides, G. J., \& Stylianides, A. J. (2010). Mathematics for teaching: A form of applied mathematics. Teaching and Teacher Education, 26(2), 161-172. 
https://doi.org/10.1016/j.tate.2009.03.022

Sulaeman, D., \& Mona, L. (2017). Sekolah Kejuruan Sebagai Corporate Social Responsibility Djarum Foundation. Wacana, 16(2), 264-278.

Turgut, M., Yenilmez, K., \& Anapa, P. (2014). Symmetry and rotation skills of prospective elementary mathematics teachers. Bolema - Mathematics Education Bulletin, 28(48), 383-402. https://doi.org/10.1590/1980$4415 \mathrm{v} 28 \mathrm{n} 48 \mathrm{a} 19$

Wardani, D. (2016). Tantangan dan Harapan Revitalisasi SMK di Indonesia Menuju Lembaga Vocational yang Berdaya. Retrieved July 4, 2019, from http://simposium.gtk.kemdikbud.go.id/karya/files/dikmen_2/DaniWard ani,S.Hum.,M.Pd._28102016231905.pdf 